3. Яночкина 3.А., Букина Т.Ф. Об остатках шиповатых микроорганизмов и следах их жизнедеятельности в триасовых отложениях Мангышлака и Устюрта // Стратиграфия и палеонтология триасовых отложений Мангышлака и Устюрта. М., 1984.

4. Букина Т.Ф. О находках голотуриеподобных организмов и следах их жизнедеятельности в триасовых отложениях Западной Сибири // Триас Западной Сибири. Новосибирск, 2001. С. 172-175.

5. Букина Т.Ф., Яночкина 3.А. Биогенная минерализация организмов пригидротермальных сообществ триаса Мангышлака, Прикаспия, Западной Сибири // Минералогия и жизнь: происхождение биосферы и коэволюция минералбного и биологического миров, биоминералогия: Материалы IV междунар. семинара. Сыктывкар. 22-25 мая 2007 г. Сыктывкар, 2007. С. 86-87.

6. Московский Г.А., Свидзинский С.А. Соотношение ритмопачек и циклов седиментации в галогенных разрезах Северного Прикаспия // Советская геология. 1989. № 5. C. $49-54$.

УДК.551.763.3:563 (470.44)
7. Свидзинский С.А., Музалевский М.М., Ковальский Ф.И. Гремячинское месторождение сильвинитов // Новые данные по геологии соленосных бассейнов Советского Союза. M., 1986. C. 204-219.

8. Липатова В.В. О германском типе триаса в Прикаспийской впадине // Изв. АН СССР. Сер. Геол. 1967. № 1. C. 17-32.

9. Наумов А.Д. Пенеплены. Их геологическое значение как особой генетической категории материков. Саратов, 1981. C. 404.

10. Бабич Д.А., Самойлович В.Л. Хабарова Т.Н. О необычном характере пограничных слоев мела и юры в низовьях Волги // Докл. АН СССР. 1975. Т. 222, № 6. C. 1401-1403.

11. Липатова В.В. Триас юго-востока Восточно-Европейской платформы: Автореф. дис. ... д-ра геол.-минер. наук. Л., 1974.36 c.

12. Триас Прикаспийской впвдины и перспективы его нефтегазоносности / Под. ред. В.В. Липатовой. М., 1982. 152 с. (Тр. ВНИГНИ. Вып. 236).

\title{
СТРАТИГРАФИЯ САНТОН-КАМПАНСКИХ ОТЛОЖЕНИЙ ЮГО-ВОСТОКА РУССКОЙ ПЛИТЫ НА ПРИМЕРЕ РАСЧЛЕНЕНИЯ РАЗРЕЗА У С. МЕЗИНО-ЛАПШИНОВКА И ПРОБЛЕМА ВНУТРИСАНТОНСКОЙ ГРАНИЦЫ В САРАТОВСКОМ ПОВОЛЖЬЕ
}

\section{В.М. Харитонов, Е.М. Первушов ${ }^{1}$, В.А. Фомин ${ }^{1}$ \\ Саратовский государственный университет, отделение геологии НИИ ЕН \\ E-mail: niig@sgu.ssu.runnet.ru \\ ${ }^{1}$ кафедра исторической геологии и палеонтологии \\ E-mail: pervushovem@mail.ru}

Представлены результаты интерпретации биостратиграфического расчленения сантонских - кампанских отложений правобережья Саратовской области на примере проведенного ранее детального и комплексного изучения разреза в районе села Мезино-Лапшиновка. Изложены представления о достоверности вариантов детального, на уровне подъярусов, подразделения сантонского яруса применительно к территории правобережного Поволжья.

Ключевые слова: сантон-кампан, Саратовское Поволжье, разрез, стратиграфия, граница.

Stratigrafy of Santonian-Campanian Deposits of South-Easten Russian Platform on the Example of Section Separation Near the Village Mezino-Lapshinovka and the Problem of Intrasantonian Boundary in the Saratov Volga Region

\section{V.M. Kharitonov, E.M. Pervushov, V.A. Fomin}

The results of interpretation of biostratigraphic separation of santonian-campanian deposits of the Saratov right-bank Volga region, on the example of earlier conducted detailed and complex investigation of separation near the village Mezino-Lapshinovka have been pre-

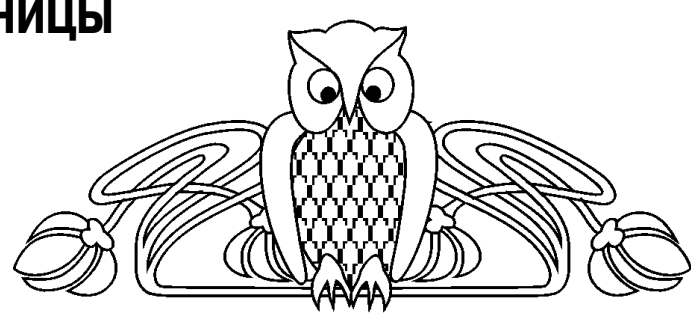

sented. The ideas of realiability of variants of the detailed (on the level of subtages) subdivision of santonian substage in reference to the territory of the Volga right-bank have been given.

Key words: santonian-campanian, Saratov Volga River Basin, crosssection, stratigraphy, boundary.

Территория европейской части России очень богата запасами углеводородного, рудного и нерудного минерального сырья. Нерудное минеральное сырье представлено писчими мелами, известняками, мергелями, песками, кремнистыми породами, фосфоритами и др., широко используемыми в различных отраслях народного хозяйства. Сейчас существует настоятельная потребность в поисках, разведке и доразведке месторождений нерудного минерального сырья с целью подсчета и увеличения их запасов. Все это связано с проведением геологосъемочных работ и расчленением опорных разрезов, в том числе и верхнемеловых отложений. В этом отношении очень интересным является разрез, расположенный в правобережной части Саратовской области у с. Мезино-Лапшиновка (рисунок). 


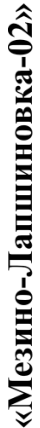

胥

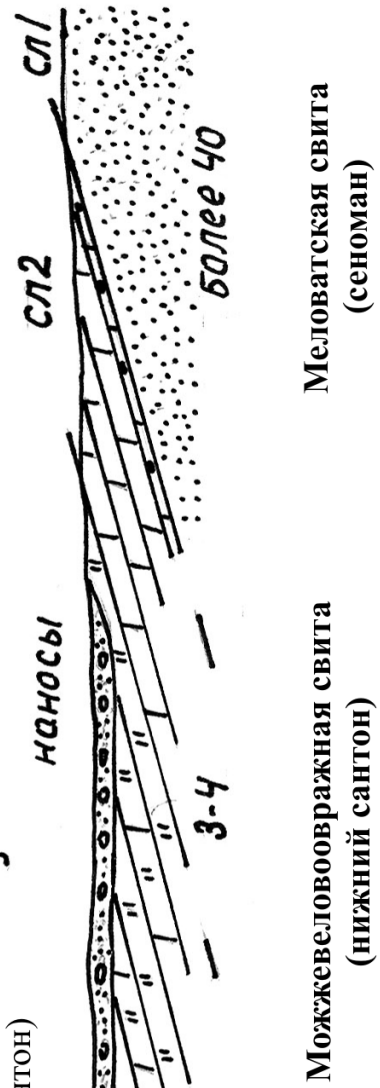

时

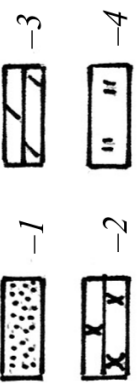

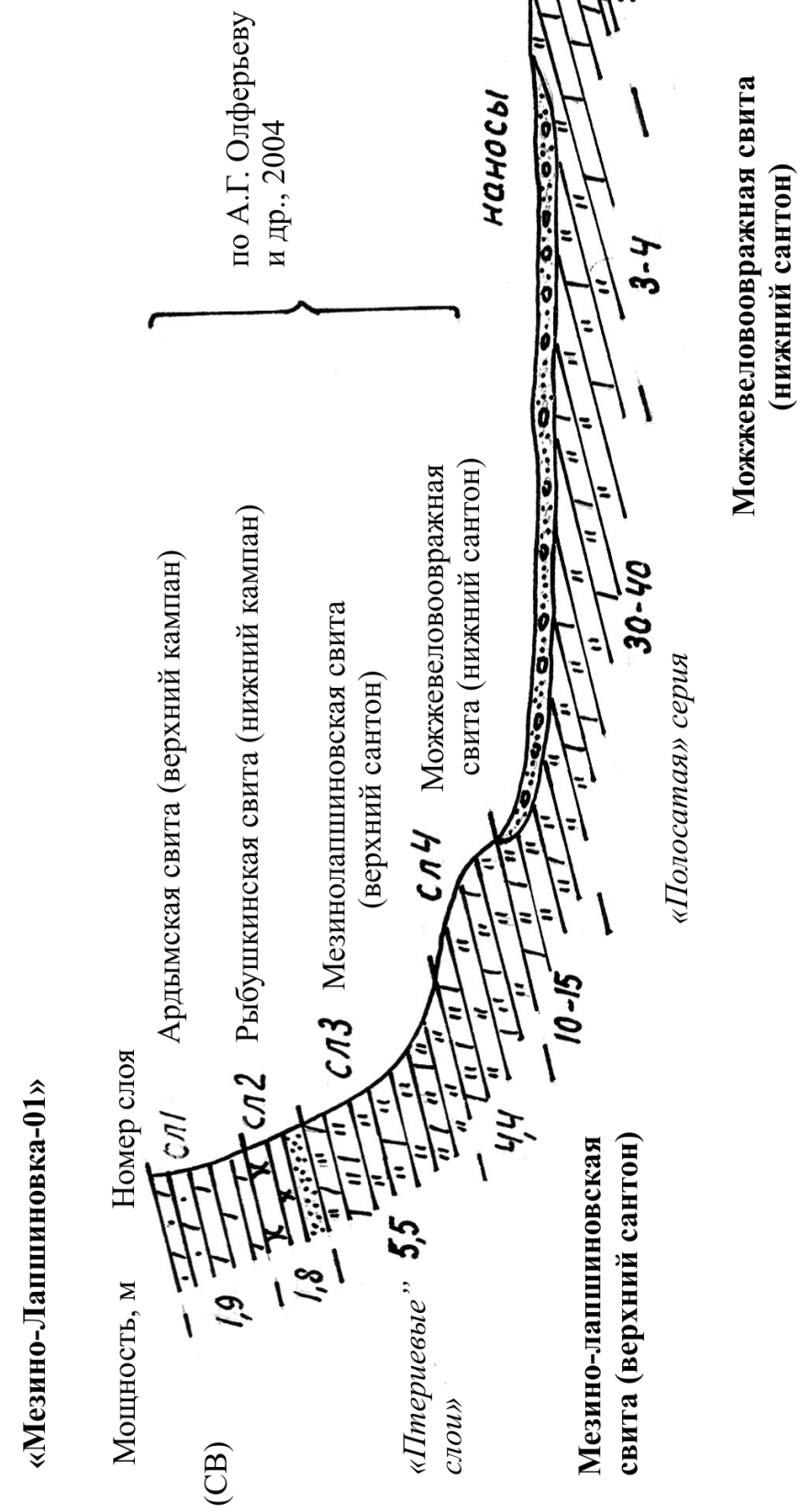


Сводный разрез нижней части верхнемеловых отложений в районе с. Мезино-Лапшиновка изучен, как видно из рисунка, по двум карьерам, расположенным северо-западнее и северо-восточнее центра данного села. Эти геологические объекты расположены на северном крыле Хлебновской брахиантиклинали при субширотном простирании слоев. В одном из карьеров, наиболее крупном, вскрываются значительные по мощности мергели и опоки (разрез «Мезино-Лапшиновка-01»), а в другом - пески с залегающими на них мергелями (разрез «Мезино-Лапшиновка-02»). Расстояние между карьерами составляет около 2 км, а интервал разреза между ними задернован, лишь спорадически прослеживаются выходы темно-серых опок и кремнистых глин.

В опоково-мергельном карьере разрез верхнемеловых отложений представляется следующим образом (описание приводится сверху вниз):

Слой 1 (Ардымская свита, низы верхнего кампана, зона Hoplitoplacenticeras coesfeldiensis) представлен чередованием светло-серых, тонко-, мелкослоистых, плитчатых мергелей, иногда сильноглинистых, переходящих в окремнелые, известковистые глины. В этих отложениях встречен богатый позднекампанский фаунистический комплекс: Baculites anceps Lam., Hoplitoplacenticeras coesfeldiensis coesfeldiensis (Schlüt.), H. cf. vari (Schlüt.), Trachyscaphites gibbus (Schlüt.), Hoploscaphites roemeri (d'Orb.), H. roemeri (d'Orb. in. Schlüter 1876, II Teil, taf.XLII, fig.4, 5), Belemnitella mucronata mucronata (Schlöth.), B. mucronata senior Now., B. langei Schatsk., Cataceramus barabini (Mort.), C. buguntaensis (Dobr. et Pavl.), C. balticus Boehm, C. convexus (Hall et Meek), C. decipiens (Zitt.), C. regularis (d'Orb.), C. pseudoregularis (Sorn.), C. wegneri (Boehm), Trochoceramus monticulii (Fugg. et Castn.), Syncyclonema splendens (Lah.), Microchlamys pulchella (Nilss.), Monticulina vesicularis (Lam.), Acutostrea curvirostris (Nilss.), Gryphaeostrea lateralis Nilss., Calliostoma mariae (Müll.), Turritella sp., Micraster sp., Echinocorys sp. и губки. Мощность слоя составляет 1,9 м.

Отложения, перекрывающие ардымскую свиту, в разрезе «Мезино-Лапшиновка-01» не вскрываются.

Слой 2 (Рыбушкинская свита, нижний кампан, зона Bellemnocamax mammilatus (Nilss.)) в верхней части представлен мелко-, среднезернистым, зеленовато-серым, кварц-глауконитовым, довольно плотным песчаником. Нижняя часть свиты представлена мелко-, среднезернистым, светло-серым, зеленоватым песком с желваками фосфорита. Здесь найдены и определены остатки Belemnocamax mammilatus mammilatus (Nilss.), $B$. mammilatus volgensis Najd., Belemnitella mucronata mucronata (Schlöth.), B. mucronata senior (Now.), Inoceramus dariensis Moskw., Monticulina vesicularis (Lam.), Gryphaeostrea lateralis (Nilss.), Oxytoma tenuicostata (Roem.), O. intermedia A. Ivanov, Microchlamys pulchella (Nilss.), Rhizopoterion cervicorne (Goldf.), Sororistips tubiforme (Schram.) и др. Мощность слоя 1,8 м.

Слои 3 и 4 (Мезинолапшиновская свита, верхний сантон, зона Sphenoceramus patootensis - S. pinniformis) слагаются чередованием преимущественно светлых, трепельных мергелей, темно-серых опок, кремнистых мергелей с подчиненными по мощности прослоями тонко-, мелкозернистых, светло-серых песков и серых глин. Отложения содержат довольно часто встречающиеся остатки Actinocamax verus fragilis Arkh., Belemnitella praecursor Stoll., Oxytoma tenuicostata (Roem.), Liostrea wegmaniana (d'Orb.), Gryphaeostrea lateralis (Nilss.), Acutostrea acutirostris (Nilss.). Сравнительно реже отмечается присутствие в кремнистых отложениях Paractinocamax grossuvrei depressus (Andreae), Sphenoceramus patootensis (Lor.), S. cf. pinniformis (Willet), Monticulina hippopodia (Nilss.). Общая мощность слоев 9,9 м.

А.Г. Олферьев с соавторами $[1$, с. 70$]$ нижнюю часть слоя 4 мощностью 4,4 м относит к можжевеловоовражной свите нижнего сантона, что вряд ли оправданно. Слои 3 и 4 представляют собой однородное чередование кремнистых и реже песчанистых и глинистых пород, содержащих остатки одной и той же фауны в классическом понимании «птериевых» слоев. Она не характерна для нижнего сантона, в котором обязательно присутствие Sphenoceramus cardissoides (Goldf.), S. pachti (Arkh.), S. lesginensis (Dobr. et Pavl.), Cordiceramus cordiformis (Sow.), C. boehmi (Müll.) и других нижнесантонских иноцерамусов, а также многочисленных губок и некоторых морских ежей. Представители этих раннесантонских форм отсутствуют в слое 4, а такие позднесантонские иноцерамы, как Sphenoceramus patootensis (Lor.) и $S$. pinniformis (Willet) присутствуют не только в слое 3 , но и в слое 4. В данном случае мы не придерживаемся известного критерия обоснования возраста вмещающих отложений по уровню первого появления (first occurrence) в разрезе представителей стратиграфически значимой группы. Уровень первого появления какого-либо вида устанавливается усредненно, по изучению распределения представителей палеофаун во многих разрезах рассматриваемого региона. Установление биостратиграфических границ между различными стратиграфическими подразделениями наиболее обоснованно может проводиться не по первому появлению какого-то, даже очень важного, вида, а по массовой смене руководящих, ортостратиграфических комплексов, знаменующих крупные этапы их эволюционного развития. Безусловно, в теоретических дискуссиях вполне понятна логика исследователей, стремящихся детально выделить некие рубежи истории развития той или иной группы ископаемых организмов. Но практика полевых стратиграфических и геологосъемочных работ, особенно исходя из опыта 
отечественной биостратиграфии, на данный момент показывает состоятельность ранее разработанных методов стратификации разрезов осадочных образований.

Вполне вероятно, что при установлении возраста пород слоя 4 предпочтение было отдано результатам изучения комплекса фораминифер. Но ознакомление с ассоциациями фораминифер $[2,3]$ показывает, что значительное большинство руководящих видов являются характерными для нескольких ярусов и подъярусов. Например, Neoflabellina suturalis (Cusm.) - нижний и верхний сантон, Stensioina exculpta (Reuss.) - сантон и выше, Gavilinella stelligera (Marie) - сантон и выше, Cibicides eriksdalensis (Brotz.) - коньяк и сантон, Stensioina pommerana (Brotz.) - верхний сантон и выше и т.д. Кроме того, в статье [1] при обосновании раннесантонского возраста слоев 1-6 (в данной работе - слой 4) имеется очень интересное замечание, что зона Gavilinella infrasantonica охватывает в Западной Европе пограничные слои среднего и верхнего сантона или верхний сантон. Это подтверждает наше предположение, что слой 4 является частью верхнесантонских образований, «птериевых» слоев. Все вышесказанное относится и к данным, полученным при изучении радиолярий и наннопланктона.

По-видимому, граница между породами верхнего и нижнего подъярусов сантона, а также между образованиями Можжевеловоовражной и Мезинолапшиновской свит авторами статьи [1] проводилась по литологическому признаку - по какому-либо реперному пропластку песка. Однако такие пласты в ритмичном чередовании кремнистых пород и песков встречаются довольно часто и обоснование привязки стратиграфических границ в данном случае лишь по одному из них трудно признать абсолютно верным.

В разрезе «Мезино-Лапшиновка-02» выделены следующие образования (описание приводится сверху вниз):

Слой 1 (Можжевеловоовражная свита, нижний сантон, зона Sphenoceramus cardissoides) представлен чередованием светло-серых, глинистых, иногда песчанистых и кремнистых мергелей с очень тонкими прослоями глин, и мелкими включениями фосфоритов с $S$. cardissoides Goldf. Мощность слоя около 3-4 м.

Сверху мергели перекрываются темносерыми, кремнистыми глинами и опоками «полосатой серии», которая нами относится к Мезинолапшиновской свите верхнего сантона. Мергели Можжевеловоовражной свиты с большим перерывом и с угловым несогласием залегают на сеноманских отложениях (меловатская свита).

Слой 2 (Меловатская свита) сложен разнозернистыми серо-желтыми песками, алевритистыми, в верхней части сильно ожелезненными, красного и оранжевого цвета. В кровле отмечены редкие находки выветрелых остатков зубов акул. Мощность песков более $40 \mathrm{M}$.
Особый интерес, несомненно, в разрезах у c. Мезино-Лапшиновка представляет собой интервал разреза тех отложений, которые расположены между слоем 4 (верхний сантон) в разрезе «Мезино-Лапшиновка-01» и слоем 1 (нижний сантон) в разрезе «Мезино-Лапшиновка-02». Он слагается кремнистыми и трепельными мергелями, опоками, кремнистыми глинами мощностью приблизительно 40-50 м. Такие параметры мощности отложений получаются при пересчете значений видимых мощностей этого интервала как на местности, так и по геологической карте масштаба 1 : 200 000. В сводном геологическом разрезе, приведенном к этой карте, указывается, что мощность сантона изменяется от 18 до 62 м, что не противоречит нашим подсчетам.

Мезинолапшиновская свита, если ее понимать как совокупность кремнистых пород, расположенных между зеленоватым песчаником нижнего кампана (рыбушкинской свиты) и светло-серыми мергелями нижнего сантона (можжевеловоовражной свиты), имеет довольно значительную мощность. По материалам изучения разрезов, расположенных на территории Саратовской области (сел Пудовкино, Багаевка, Лысая гора, Вишневое, Нижняя Банновка), она изменяется от 20 до 40 м. Анализ мощностей кремнистых образований, выделенных из них фаунистических комплексов и известных опубликованных данных, позволяет предполагать, что в разрезе «МезиноЛапшиновка-01» прослеживается не полный вещественный объем Мезинолапшиновской свиты, а только верхняя часть этих образований, которая может рассматриваться как верхи «птериевых» слоев. Нижние интервалы образований свиты мощностью 10-15 м скрыты наносами. Предполагается, что здесь распространены остатки тех же фоссилий, что известны из слоев 3 и 4, а также остатки иноцерамусов S. lobatus (Münst.) (Goldf.) и $S$. lingua (Goldf.), находки которых сделаны в породах «птериевых» слоев в разрезах Саратова (Лысая гора), с. Пудовкино и Мордовии.

Ниже «птериевых» слоев располагается «полосатая» серия, представленная чередованием светлых и темно-серых кремнистых пород с очень редкими остатками ростров белемнитов: Actinocamax verus fragilis Arkh., A . propinqua Mob., Belemnitella praecursor Stoll. Мощность отложений свиты изменяется от 30 до 40 м.

«Птериевые» слои и «полосатая» серия являются исторически традиционными единицами местной, литостратиграфической шкалы верхнемеловых отложений в пределах Русской плиты. История их выделения, эволюция взглядов на их стратиграфические объемы и геохронологическое положение заслуживают особого внимания. Ведь речь идет о решении очень важного стратиграфического вопроса о проведении внутрисантонской границы, одной из самых сложных в проблематике верхнемеловой стратиграфии. Вопрос о возрасте сантонских отложений, включающих губковый го- 
ризонт, мергели зоны S. cardissoides, «полосатую» серию кремнистых и трепельных мергелей, силицитов (опок) и кремнистых глин, «птериевые» слои, аналогичные по литологическому составу вышеуказанной серии, рассматривался ранее биостратиграфами различно.

Выдающийся исследователь верхнего мела Восточно-Европейской платформы А.Д. Архангельский [4] верхнеконьякскую зону Volviceramus involutus справедливо относил к эмшеру, а зоны Sphenoceramus pachti и Pteria tenuicostata к нижнему сенону. Зона S. pachti была им отнесена к нижнему сантону, а зона Pteria tenuicostata $-\kappa$ верхнему. В 1912 году А.Д. Архангельским [4] выделялись «кардиссоидные» слои и «полосатая» серия, залегающие на «губковом» горизонте. Но им было высказано предположение о том, что зона Pteria (Oxytoma) tenuicostata может соответствовать «квадратовым» слоям - зона Gonioteuthis quadrata нижнего кампана Германии.

Е.В. Милановский [5] и А.Е. Глазунова [6] то отождествляли «полосатую» серию с «губковым» горизонтом и мергелями «кардиссоидной» зоны, то их разделяли, в последнем случае «полосатая» серия занимала верхнюю часть нижнего сантона. В «полосатой» серии остатков палеоофауны, кроме редких белемнитов, не отмечалось. Образование «птериевых» слоев указанные авторы рассматривали в составе верхнего сантона.

Д.П. Найдин [7], долгое время и весьма плодотворно изучающий стратиграфию верхнемеловых отложений Русской плиты, «губковый» горизонт и мергели зоны S. cardissoides четко отделяет от «полосатой» серии и, на наш взгляд, совершенно правильно отождествляет их с нижним сантоном. «Полосатая» серия опок, кремнистых мергелей и глин так же совершенно обоснованно оказывается в составе верхнесантонского подъяруса, а «птериевые» слои считаются нижнекампанскими. В более поздней работе Д.П. Найдин [8] указывает, что «птериевые» слои надежно отделяются от «полосатой» серии по литологическим признакам. Тем не менее следует указать, что провести такое разделение в толще однообразного чередования кремнистых пород далеко не всегда просто.

Впервые Можжевеловоовражная и Мезинолапшиновская свиты как единицы местной стратиграфической шкалы были установлены саратовскими геологами геологического факультета СГУ и НИИ геологии СГУ. Взгляды на стратиграфический объем, особенности литологического строения и последовательность выделения свит постоянно претерпевали естественную в таких случаях эволюцию. Е.М. Первушов, А.В. Иванов, Е.В. Попов [9]. Можжевеловоовражную свиту не выделяли, а Мезинолапшиновская свита была представлена двумя подсвитами. Нижняя подсвита слагалась карбонатно-мергельно-терригенными породами и охватывала «губковый» горизонт, мергели и глины c Sph. cardissoides нижнего сантона, фаунистически хорошо охарактеризованные. Верхняя подсвита состояла преимущественно из комплекса кремнистых пород, где остатки беспозвоночных и фораминифер очень редки. Нет никакого сомнения, что в состав верхней подсвиты включались и «полосатая» серия, и «птериевые» слои.

А.В. Иванов, Е.М. Первушов в работе [10] описывают Можжевеловоовражную свиту, на основании изучения разреза у с. Пудовкино в ее вещественном составе выделяется «губковый» горизонт и светлые мергеля «кардиссоидной» зоны нижнего сантона. Все кремнистые слои уже относятся к Мезинолапшиновской свите верхнего сантона, которая заключает в себе как «полосатую» серию, так и «птериевые» слои. Такое расчленение кажется нам наиболее обоснованным, потому что оно в наибольшей степени соответствует принципам выделении единиц местной литостратиграфической шкалы.

П.Н. Якушин, А.В. Иванов [11] приводят несколько иное возрастное и литостратиграфическое обоснование Можжевеловоовражной и Мезинолапшиновской свит. Это обоснование, несомненно, основывается на данных, приведенных в стратиграфической схеме верхнемеловых отложений Восточно-Европейской платформы, составленной под общим руководством и редакцией А.Г. Олферьева, принятой в качестве официальной на Межведомственном региональном совещании и утвержденной МСК России в 2001 г.

Мы приводим полностью определения Можжевеловоовражной и Мезинолапшиновской свит, опубликованные в работе [11]. Можжевеловоовражная свита представляет собой чередование мелоподобных и кремнеземистых мергелей с «губковым» горизонтом в основании. Верхняя граница проводится неоднозначно. Мезинолапшиновская свита выражена чередованием кремнеземистых и мелоподобных мергелей, сланцеватых глин и силицитов. Нижняя граница с подстилающими отложениями Мезинолапшиновской свиты проводится не всегда уверенно, чаще по данным микрофаунистического анализа или по наличию базального горизонта, или по резкой смене литологического состава пород. Верхняя граница всегда отчетливо выражена благодаря губковомоллюсковому горизонту с обилием фосфоритов, который подстилает вышележащие отложения пудовкинской свиты.

Здесь представляет интерес положение о том, что при проведении границы между этими свитами ее положение обосновывается микрофаунистически, т.е. основываясь на результатах изучения распределения представителей микрофауны. Однако применение данных микропалеонтологии при проведении границ межу свитами входит в некоторое противоречие с самим понятием «свита». Под «свитой» обычно понимается одна из единиц местной литостратиграфической шкалы, характеризующаяся определенными параметрами, свойствами и качествами, т.е. призна- 
ками, позволяющими отличать это геологическое тело, свиту, от сопряженных геологических тел, единиц местной литостратиграфической шкалы. Это геологическое тело, свита, должно быть хорошо распознаваемо на местности, однородно по литологическому составу и иметь литологически четко выраженные границы, быть выдержанным и распространенным, достоверно представленным в регионе. Только в таком случае возможно осуществление картирования свит и их границ. Изначальное установление границ между свитами по распределению остатков микрофауны при выделении свит в полевых условиях весьма усложняет проведение геологической съемки.

Проведение границы между свитами по базальному горизонту или резкой смене литологического состава порой также весьма затруднительно, потому что в условиях непрерывного осадконакопления, ритмичного чередования кремнистокарбонатно-терригенных пород, определить наличие значимого для целей стратификации интервала разреза, базального горизонта или резкую смену состава пород практически невозможно.

А.Г. Олферьев с соавторами [1] в разрезе у с. Мезино-Лапшиновка верхнюю часть «птериевых» слоев относит к Мезинолапшиновской свите верхнего сантона, а нижнюю часть слоев с Oxytoma tenuicostata к Можжевеловоовражной свите нижнего сантона. Из рисунка видно, что в состав этой свиты включаются также кремнистые и трепельные мергели, опоки и глины «полосатой» серии, мергели зоны S. cardissoides и «губковый» горизонт. Несомненно, что такое проведение внутрисантонской границы, а также границы между свитами основывалось на распределении в разрезе комплекса фораминифер и на весьма ненадежных литологических признаках.

Возможно, основой представленного варианта интерпретации построения разреза «МезиноЛапшиновка-01» является очень детальное расчленение маломощных слоев на прослойки и пласты. При таком расчленении и наличии большого количества макро - и микрофаунистического материала резко увеличивается влияние субъективного фактора при оценке значимости фаунистических комплексов для установления возраста вмещающих отложений, т.е. при интерпретации данных. При этом часто происходит некоторая концентрация внимания исследователей на обнаружение ложных, несуществующих закономерностей. Появление их обусловливается такими обстоятельствами, как, например, присутствие или отсутствие остатков фауны в слое, нахождение или ненахождение ее, количественные характеристики, т.е. объемы выборки, правильное или неправильное определение фауны и каким автором и т.д. Для разрешения традиционно широкого круга подобных вопросов необходимо применение математической статистики и привлечение большого круга палеонтологов, специалистов по конкретной группе организмов.
Традиционным способом возможного преодоления неточностей при расчленении отложений является сопоставление известных особенностей распределения остатков палеофауны в исследуемом разрезе с выявленными биостратиграфическими закономерностями по сопряженным геологическим объектам с аналогичными интервалами отложений. В последующем осуществляется сопоставление изученных интервалов отложений сопредельных регионов и далее с разрезами, известными и изученными в отдаленных регионах, в частности, со стратотипическими или парастратотипическими разрезами Германии, Франции и США.

Полезным для расчленения сантонских отложений Поволжья является сопоставление выявленного здесь распределения фаун с известными особенностями распространения беспозвоночных в синхронных образованиях Дагестана. Для этого мы используем опорный разрез у сел Аймаки и Охли. Данные по распределению верхнемеловой фауны в разрезе нами взяты из работ [3, 12-14]. Здесь карбонатные сантонские отложения согласно залегают на верхнем коньяке. Граница проводится по массовой смене инволютных иноцерамов рода Volviceramus иноцерамидными двустворчатыми моллюсками родов Cladoceramus, Cordiceramus и Sphenoceramus. Некоторые редкие, единичные, представители этих родов могут встречаться и в отложениях верхнего коньяка.

В разрезе у сёл Аймаки и Охли мощность карбонатных образований составляет 110-120 м. Нижние 10-20 м представлены чередованием зеленых, мелко-, среднеслоистых глинистых известняков и мергелей, содержащих обильные остатки беспозвоночных, датирующих возраст вмещающих пород как нижнесантонский. Часто встречаются аммониты родов Stantonoceras, Nowakites, морские ежи родов Micraster, Cardiaster, Offaster, Echinocorys, Conulus и др. Здесь выделяются две иноцерамовые зоны: Cladoceramus undulatoplicatus michaeli и Cordiceramus cordiformis. Мощность отложений каждой из зон по 5-10 м. В составе этих биозон встречаются одни и те же иноцерамы: Cladoceramus undulatoplicatus michaeli Heinz, Sphenoceramus cardissoides (Goldf.), S. pachti (Arkh.), S. lesginensis (Dobr. et Pavl.), Cordiceramus cordiformis (Sow.), C. boehmi (Müll.), Magadiceramus subquadratus (Schlüt.), Platyceramus cycloides (Wegn.). В верхней биозоне увеличивается количество кордицерамов.

Выше по разрезу, в плотных, толстослоистых белых и розовых известняках мощностью около 70-80м, количество фауны резко сокращается. Это так называемые немые слои $[12,13,15]$ верхнего сантона. Здесь очень редко встречаются крупные плоские иноцерамусы, определенные В.П. Ренгартеном [16] как Platyceramus mantelli (de Mercey) Barrois. В литературе [15, 16] имеются упоминания об очень редких находках здесь Sphenoceramus patootensis (Lor.), S. steenstrupi (Lor.), 
Cataceramus daghestanensis (Dobr. et Pavl.), а также морских лилий Uintacrinus и Marsupites.

Выше, в таких же известняках количество фауны резко увеличивается, и она, также верхнесантонская, становится весьма разнообразной. Это иноцерамы Cataceramus daghestanensis (Dobr. et Pavl.), C. balticus (Boehm), Cordiceramus aff. boehmi (Müll.), C. besairiei (Heinz), C. haenleini (Müll.), Cremnoceramus brancoi (Wegn.), Platyceramus cycloides (Wegn.), Sphenoceramus patootensis (Lor.), S. lobatus (Münst.) Goldf., S. steenstrupi (Lor.), аммониты Gaudryceras varagurense Kossm., морские ежи родов Offaster, Paronaster, Ornithaster, Micraster, Isomicraster, морские лилии родов Uintacrinus, Marsupites, Bourguieticrinus, Austinocrinus.

Отложения верхнего сантона согласно перекрываются толстослоистыми известняками нижнего кампана, представленными четырьмя последовательно залегающими друг на друге иноцерамовыми зонами: Cataceramus dariensis, Cordiceramus azerbajdjanensis, C. mülleri - Cataceramus agdjakendensis, Platyceramus madjalissensis [12-14]. Здесь присутствует очень богатая иноцерамовая фауна, встречаются аммониты Eupachydiscus, Hauericeras, Pseudoschloenbachia, Baculites, морские ежи Conulus, Echinocorys, Offaster, Galeola, Paronaster, Seunaster, Pseudoffaster, Ornithaster, Isomicraster, морские лилии Bourgueticrinus.

Из вышеизложенного видно, что биостратиграфическое расчленение сантонских отложений Дагестана трудностей не доставляет. Этот вариант биостратиграфического расчленения сантонских и сантонских - кампанских отложений вполне можно сопоставить с таковым в Поволжье. Две зоны нижнего сантона Дагестана - Cladoceramus undulatoplicatus michaeli и Cordiceramus cordiformis - вполне сопоставимы с отложениями зоны S. cardissoides Поволжья. Палеонтологическая характеристика зоны S. cardissoides содержит те же виды иноцерамов, что и одновозрастные отложения Дагестана, включая и Cladoceramus undulatoplicatus michaeli (Heinz), Cordiceramus cordiformis (Sow.), C. boehmi Heinz. Последние впервые найдены совсем недавно в разрезах сёл Озерки-2 и Пудовкино. Особенностью палеонтологической характеристики зоны S. cardissoides является отсутствие аммонитов и некоторых морских ежей и заметное распространение кремниевых губок, актинокамаксов и белемнителл, что рассматривается как проявление существовавшей климатической зональности.

Нижнесантонские отложения в Поволжье либо согласно залегают на мергелях верхнего коньяка (зона Volviceramus involutus) в южной части Саратовского правобережья (разрез у с. Нижняя Банновка), либо со значительным эрозионным срезом перекрывают терригенные породы сеномана (Саратовские дислокации, РтищевскоБаландинский вал). В серии разрезов Вольского района сантонские отложения отсутствуют. По периферии Саратовских дислокаций в ряде изученных разрезов (села Багаевка, Вишневое, Озерки, Пудовкино) между песками сеномана и мергелями зоны Sphenoceramus cardissoides прослеживается слой мелоподобных пород туронского - коньякского возраста.

Продолжая сопоставление сантонских отложений Дагестана и Поволжья, можно проследить, что количество фауны в немых слоях в Дагестане и «полосатой» серии Поволжья резко сокращается. В «полосатой» серии пока найдены Actinocamax и Belemnitella, а в немых слоях - иноцерамусы и морские ежи верхнего сантона. Геологическое и стратиграфическое положение сопоставляемых слоев говорит об их относительной синхронности. Вполне возможно, что в «полосатой» серии будут найдены S. patootensis (Lor.) и другие иноцерамусы, известные из синхронных образований Дагестана. Комплекс микрофауны фораминифер «полосатой» серии Поволжья, немых слоев Дагестана [17], Крыма [2], Копетдага [18] и Западной Европы (Германия, Англия) [19] один и тот же, и встречается он совместно с позднесантонскими морскими лилиями Uintacrinus и Marsupites. Можно предположить, что немые слои верхнего сантона Дагестана являются южным аналогом «полосатой» серии Поволжья.

Сопоставление отложений верхней части верхнего сантона Дагестана с кремнистыми образованиями «птериевых» слоев с большой степенью уверенности указывает на их синхронность. В отложениях присутствуют Sphenoceramus patootensis (Lor.), S. lobatus (Münst.) Goldf., Platyceramus cycloides (Wegn.) и сходный комплекс микрофауны. В Крыму и в Копетдаге в этом интервале отмечено наличие Actinocamax verus fragilis Mill. и Belemnitella praecursor Stoll. Эти белемниты в Западной Европе [20] встречаются совместно с Oxytoma tenuicostata (Röm.), Liostrea wegmaniana (d'Orb.), Gryphaeostrea lateralis Nilss., Acutostrea acutirostris (Nilss.), Monticulina hippopodia (Nilss.), Paractinocamax grossuvrei depressus (Andreae), Sphenoceramus patootensis (Lor.), S. steenstrupi (Lor.), S. pinniformis (Willet), S. tuberculatus (Woods), S. lobatus (Münst.) Goldf., Platyceramus cycloides (Wegn.), Cordiceramus besairiei (Heinz), C. haenleini (Müll.), морскими ежами и лилиями Micraster, Isomicraster, Offaster, Paronaster, Ornithaster, Uintacrinus, Marsupites, Austinocrinus. Из этого списка познесантонской фауны можно сделать вывод об идентичности возраста «птериевых» слоев Поволжья и верхней части верхнего сантона Дагестана, которые являются южным аналогом слоев с Pteria (Oxytoma). Верхнесантонские карбонатные немые слои и верхи с богатым комплексом фауны Дагестана составляют зону Cataceramus daghestanensis. В Поволжье кремнистые образования относятся к Мезинолапшиновской свите и к верхнесантонской зоне Sphenoceramus patootensis - S. pinniformis. 
Перекрывающие их зеленоватые песчаники рыбушкинской свиты (зона В. mammilatus, нижний кампан) местами (разрезы «Лысая гора», «Рыбушка») содержат, наряду с белемнитами и устрицами, руководящие иноцерамы Cordiceramus azerbajdjanensis (M. Aliev), Cataceramus dariensis (Dobr. et Pavl.), C. balticus (Boehm). Предполагаем, что эти слои, содержащие остатки иноцерамусов, являются аналогами карбонатных слоев нижнего кампана Дагестана.

Очень важным вопросом стратиграфии сантона является выделение в его структуре среднего подъяруса. В Западной Европе это стратиграфическое подразделение, средний сантон, понимается в объеме верхней зоны нижнего сантона - Cordiceramus cordiformis. Превращение этой зоны в самостоятельный подъярус сантона вряд ли правомочно, ибо во многом фаунистическая характеристика среднего подъяруса, на данный момент, аналогична таковой нижнего подъяруса. В большинстве регионов две нижнесантонские зоны полностью сливаются в одну, что характерно для большинства регионов мира, в том числе и в Поволжье. Поэтому средний сантон является искусственным образованием, выделение которого в большинстве регионов мира весьма затруднительно. При этом заметные изменения в составе фаун глобального и регионального значения происходили на уровне раннего и позднего сантона, при двучленном расчленении этого яруса (века). В Дагестане такие изменения наблюдаются между зонами Cordiceramus cordiformis нижнего сантона и Cataceramus dagestanensis верхнего сантона. В Поволжье граница проходит между зонами Sphenoceramus cardissoides и S. patootensis - S. pinniformis, на этом рубеже во многих регионах отмечается смена комплексов практически всех групп морских фаун [16, 21], включая и аммониты. Предполагается, что заметные изменения фаунистического состава на рубеже раннего и позднего сантона коррелируются с резким изменением теплового режима океанических вод.

Таким образом, в Поволжье светлые мергели нижнего сантона, «губковый» горизонт и зона S. cardissoides нами относятся к Можжевеловоовражной свите. Кремнистые образования, «полосатая» серия и «птериевые» слои верхнесантонской зоны S. patootensis - S. pinniformis отнесены к Мезинолапшиновской свите. Разрез у с. Мезино-Лапшиновка является очень интересным, но его трудно рассматривать как опорный. Скорее, это один из опорных разрезов границы сантона - кампана - региональный лимитотип. В пределах изученных разрезов отсутствуют туронские и коньякские отложения, кампан и сеноман представлены лишь редуцированными интервалами. Изучение этого разреза и особенностей распределения фауны в рассматриваемом интервале и в Поволжье чрезвычайно полезно по многим аспектам исследований и заслуживает продолжения в дальнейшем.
Работа выполнена при поддержке РФФИ (проект 06-05-64878).

\section{Библиографический список}

1. Олферьев А.Г., Алексеев А.С., Беньямовский В.Н. и др. Опорный разрез верхнего мела у села Мезино-Лапшиновка и проблема границ сантона и кампана в Саратовском Поволжье // Стратиграфия. Геол. корреляция. 2004. Т. 12, № 6. С. 69-102.

2. Атлас верхнемеловой фауны Северного Кавказа и Крыма. М., 1959. 479 с.

3. Атлас верхнемеловой фауны Донбасса. М., 1974. $640 \mathrm{c}$.

4. Архангельский А.Д. Верхнемеловые отложения востока Европейской России. СПб., 1912. Т. 25. 631 с.

5. Милановский E.B. Очерк геологии Среднего и Нижнего Поволжья. М.; Л., 1940. 276 с.

6. Глазунова A.E. Палеонтологическое обоснование стратиграфического расчленения меловых отложений Поволжья // Верхний мел. М., 1972. 204 с.

7. Герасимов П.А., Мигачева Е.Е., Найдин Д.П. и др. Юрские и меловые отложения Русской платформы // Очерки региональной геологии СССР. М., 1962. Вып. 5. 195 с.

8. Найдин Д.П. О границе между сантонским и кампанским ярусами на платформе // Граница сантона и кампана на Восточно-Европейской платформе. Свердловск, 1979. C. 7-23.

9. Первушов Е.М., Иванов А.В., Попов Е.М. Местная стратиграфическая схема верхнемеловых отложений Правобережного Поволжья // Тр. НИИ Геологии Сарат. гос. ун-та. Нов. сер. 1998. Т. 1. С. 85-94.

10. Иванов А.В., Первушов Е.М. Губковые горизонты сантона-кампана и «птериевые слои» Саратовского Поволжья // Недра Поволжья и Прикаспия. 1998. Вып. 17. C. 24-30.

11. Якушин П.И., Иванов А.В. Краткий атлас позднемеловых двустворчатых моллюсков юго-востока ВосточноЕвропейской платформы. Саратов, 2001. 116 с.

12. Алиев М.М., Павлова М.М., Харитонов В.М. Биостратиграфическое расчленение верхнемеловых отложений Дагестана по фауне иноцерамов // Изв. АН Азерб. ССР. 1982. № 4. C. 1-14.

13. Алиев М.М., Харитонов В.М. Систематический состав и фациальное распространение остреоидных и пектиноидных моллюсков в позднемеловых бассейнах Дагестана // Изв. АН Азерб. ССР. 1986. № 4. С. 1-15.

14. Харитонов В.М. Двустворчатые моллюски (иноцерамы) верхнемеловых отложений Дагестана и их биостратиграфическое значении: Автореф. дис. ... канд. геол.-минерал. наук. Баку, 1974. 25 с.

15. Алиев М.М., Харитонов В.М. Иноцерамы верхнего мела // Меловая фауна Азербайджана. Баку, 1988. C. 251-273.

16. Ренгартен В.П. Опорные разрезы верхнемеловых отложений Дагестана. М., 1965. 75 с.

17. Пергамент М.А., Смирнов Ю.П. Вертикальное распределение и стратиграфическое значение иноцерамов в верхнемеловом разрезе Дагестана // Тр. Всесоюз. коллоквиума по иноцерамам. М., 1972. Вып. 1. С. 94-113. 
18. Арзуманова E.M. Стратиграфическое и географическое распространение позднемеловых иноцерамид Туркмении // Вопросы биостратиграфии и геологии полезных ископаемых Туркменистана. Ашхабад, 1973. С. 3-15.

19. Hancock J.M., Gale A.S. et al. The Campanian Stage // Bull. de L'Royal des Sciences Naturelles de Belgique,
Sciences de la Terre. Brussel, 1996. 66-Supp. P. 103-109. 20. Пергамент М.A. История изучения иноцерамов как руководящей фауны позднего мела (1814-1960) // Материалы III и IV Всесоюз. коллоквиумов. М., 1978. С. 30-68.

21. Пергамент М.A. Стратиграфия и иноцерамы верхнего мела Северного полушария. М., 1978. 191 с.

УДК 551.782 .2 (470.45)

\section{НАДСОЛЕВЫЕ МЕЗОЗОЙСКО-КАЙНОЗОЙСКИЕ ОТЛОЖЕНИЯ ГРЕМЯЧИНСКОГО МЕСТОРОЖДЕНИЯ КАЛИЙНЫХ СОЛЕЙ}

\section{Е.Ф. Ахлестина, Г.А. Московский \\ Отделение геологии НИИ ЕН СГУ \\ E-mail: MinihMG@info.sgu.ru \\ ${ }^{1}$ Геологический факультет \\ E-mail: MoskovskyGA@info.sgu.ru}

Авторы рассматривают состав пород, вскрытых скв. 13 на Гремячинском месторождении калийных солей, расположенном в Волгоградской области. Установлен разнообразный комплекс терригенных, кремнистых, карбонатных пород и их смешанных разностей, ритмично чередующихся по разрезу позднемеловых, палеогеновых, неогеновых и четвертичных отложений. Восстанавливаются условия их формирования в морских бассейнах, развитие которых на протяжении этого длительного времени связывается с периодическим проявлением тектонических событий как глобального масштаба, так и регионального характера.

Ключевые слова: калийная соль, Гремячинское месторождение, Волгоградская область, литология, седиментация, палеогеография.

\section{Mesozoic-Cenozoic Oversalt Deposits from the Gremy- achkinskoye Sylvinite Field}

\section{E.F. Acklestina, G.A. Moskovsky}

The authors consider compositions of the rocks penetrated with the Well No 13 in the Gremyachkinskoye sylvinite field, Volgograd Region. Varied complexes of terrigenous, ciliceous and carbonate rocks, alongside with their mixed varieties rhythmically alternate there over the Late Cretaceous, Paleogene, Neogene and Quaternary sections. Reconstructions have been made of their generation settings within marine basins; the basin evolution during that lengthy period used to be associated with periodic manifestations of tectonic events of both, global and regional scales.

Key words: sylvinite, Gremyachkinskoye field, Volgograd Region, lithology, sedimentology, palaeogeography.

Гремячинское месторождение калийных солей (сильвинитов) установлено на юге Приволжской моноклинали в так называемой преднадвиговой зоне, ограниченной на юге Северо-Котельниковским разломом [1]. В тектоническом строении зоны выделяют два структурных яруса. Верхний ярус включает толщу от четвертичных до нижнемеловых отложений со

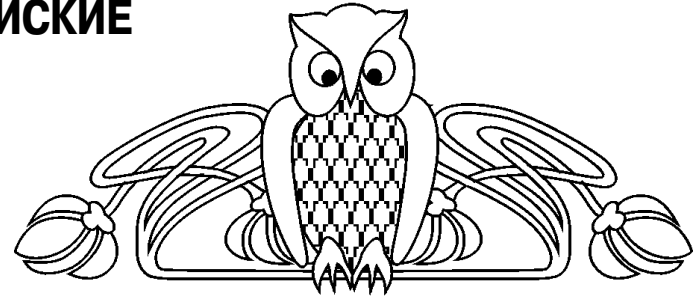

слабой дислоцированностью пород, пологим моноклинальным их погружением. Нижний ярус охватывает пермско-триасовые и каменноугольные отложения. Он характеризуется развитием локальных антиклинальных структур северо-западного простирания.

В работе авторы рассматривают наименее изученные надсолевые отложения верхнего структурного яруса, вскрытые в 2007 г. скв. 13 на Гремячинском месторождении (юг Приволжской моноклинали) в интервале 25,8-539,3м (рисунок). Они представлены терригенными, терригеннокремнистыми, терригенно-карбонатными породами позднемелового, палеогенового, неогенового и четвертичного возраста. Отложения нижнего мела и юры в данном разрезе отсутствуют. Ниже приводится описание этих отложений, основанное на результатах их комплексного минералогопетрографического изучения.

\section{Верхнемеловые отложения} (инт. 539,3-310 м)

Сеноман (инт. 539,3-501 м) представлен песками глауконитово-кварцевыми светлозеленовато-серыми мелко-, среднезернистыми. Кварц (80-85\%) присутствует в виде различно окатанных зерен размером 0,04-0,52 мм, иногда кавернозных, трещиноватых. Трещинки заполнены глауконитом. Последний составляет 10-15\%. Зерна его имеют различных тонов зеленую окраску, неправильные округлые очертания, микроглобулярное строение. Размер изменяется в пределах 0,04-0,12 мм. Отмечаются редкие частицы микроклина, плагиоклазов, обломки кремней кварц-халцедонового состава, кианит.

Турон-коньяк (инт. 501,9-464м) сложен литологически монотонной толщей мелоподобных почти белых тонкодисперсных известняков со слабовыраженными следами биотурбации, состоящих практически нацело из биогенного (кокколитового) пелитоморфного кальцита с беспорядочно рассеянными включениями фрагментов фораминифер, кальцисфер, редких алевритовых 